\title{
Synthesis of carboxy-residue-modified coenzyme derivatives as probes to the mechanism of glutathione enzymes
}

Claudius D'SILVA

Institute of Molecular and Biomolecular Electronics, University of Wales, Bangor, Gwynedd LL57 1UT, Wales, U.K.

A general procedure for the preparation of the monoglycyl and dimethyl ester and amide derivatives of $S$-(4bromobenzyl)glutathione are reported, in addition to purification procedures.

\section{INTRODUCTION}

Glutathione ( $\gamma$-glutamylcysteinylglycine) fulfils a variety of roles vital to life processes. It functions as a coenzyme (e.g. formaldehyde dehydrogenase, glyoxalase I, glutathione isomerase, glutathione peroxidase), co-substrate (e.g. glutathione $S$-transferase), substrate (e.g. $\gamma$-glutamyl transpeptidase), or as part of the substrate architecture (e.g. glyoxalase II). It also plays a vital role in the detoxification of xenobiotics, transhydrogenation reactions, protein thiol maintenance and membrane protection via the neutralization of peroxides and free radicals. Glutathione-dependent enzymes have been studied from a variety of perspectives, which include the use of chemically GSH analogues, e.g. photoaffinity labels based on GSH (Douglas et al., 1982a), $N$ - or $S$-blocked GSH derivatives as probes to GSH-binding sites (Vince et al., 1971; Vander Jagt \& Han, 1973; Askelof et al., 1975; Douglas et al., 1982b) and peptide analogues (Chen et al., 1985; Adang et al., 1989). As a consequence of the above studies it became necessary to investigate further the proposed roles of the carboxy groups of glutathione with some glutathione-dependent enzymes. To study these regions on the enzyme we needed to prepare a range of selectively modified analogues based on $S$-bromobenzylglutathione, a good competitive inhibitor of both glyoxalase I and glutathione transferase (Vince et al., 1971; Askelof et al., 1975). Esterification by the $\mathrm{HCl}$ (gas)/methanol procedure reported to be successful in the preparation of the monoglycyl ester of GSH (Vander Jagt \& Han, 1973) proved to be unsatisfactory on this occasion, possibly due to the low solubility of this $S$-blocked GSH in methanol under the reaction conditions used. Although this reaction is seemingly simple, few procedures exist for the selective methylation of carboxy residues on peptides. On the basis of the reported observation that selective methylation is achieved using thionyl chloride/methanol (Boisonnas et al., 1955) in the esterification of the $\gamma$-carboxy group $\left(\mathrm{p} K_{\mathrm{a}} 4.07\right)$ of glutamic acid, we reasoned that this selectivity was possibly a function of the higher $\mathrm{p} K_{\mathrm{a}}$ of the group, steric hindrance or a consequence of the presence of an $\alpha$-amino group. As these conditions were fulfilled by the glutathione molecule, it seemed appropriate to use this reagent in the proposed synthesis. We report now a successful and convenient approach to the selective modification of the carboxy groups of GSH in addition to purification procedures for such derivatives (5-10):

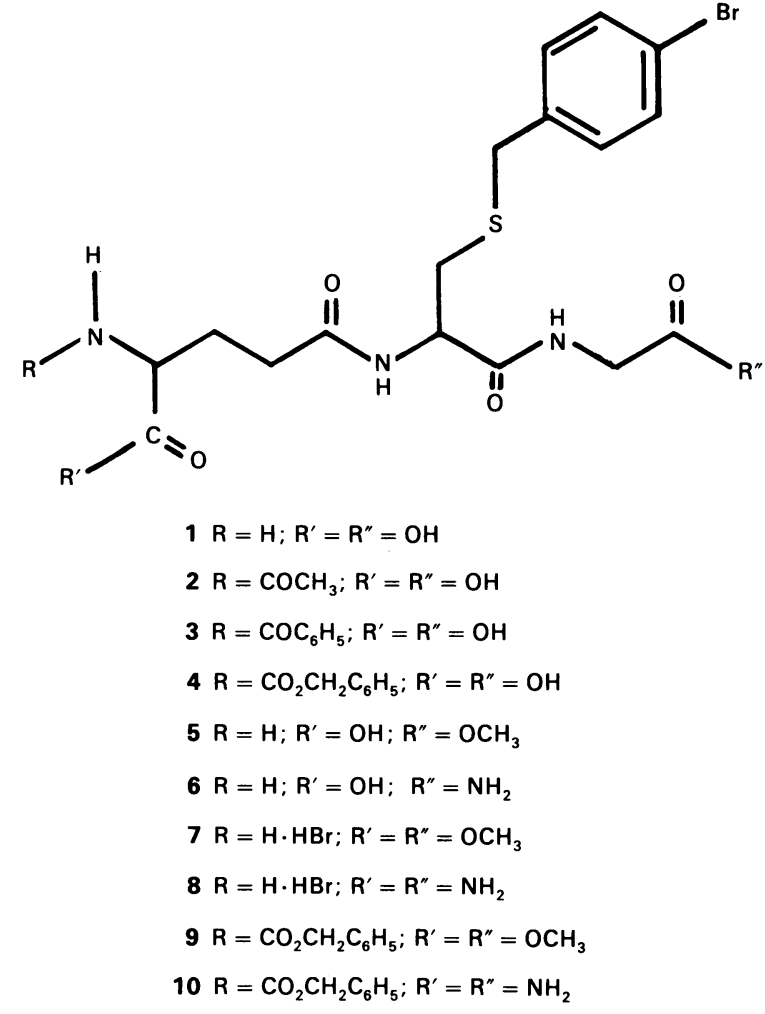

\section{EXPERIMENTAL}

Precursors and solvents were purchased commercially and purified appropriately. U.v. and visible spectra were recorded by means of a Pye-Unicam SP. 8-100 spectrophotometer at $25^{\circ} \mathrm{C}$. ${ }^{1} \mathrm{H}$ n.m.r. spectra were obtained by using a Varian EM 360 instrument and ${ }^{13} \mathrm{C}$ n.m.r. (Fourier transform) spectra recorded at $20.15 \mathrm{MHz}$ on a Brucker WP $805 \mathrm{Y}$ spectrophotometer. ${ }^{1} \mathrm{H}$ and ${ }^{13} \mathrm{C}$ chemical shifts $(\delta)$ are in p.p.m. with reference to tetramethylsilane; resonances marked with an asterisk disappeared on addition of ${ }^{2} \mathrm{H}_{2} \mathrm{O}$. Spectra were run in $\left[{ }^{2} \mathrm{H}_{6}\right]$ dimethyl sulphoxide and ${ }^{2} \mathrm{H}_{2} \mathrm{O}$. T.l.c. was performed on $0.2 \mathrm{~mm}$-thick precoated plates (Merck DC-Platik-folien Kieselgel $60 \mathrm{~F}_{254}$ ). Spots were made visible by u.v. illumination and by means of a ninhydrin/acetone spray. Tests for completion of $N$-blocking 
were carried out with ninhydrin reagent. Melting points (uncorrected) were determined with an m.p. microscope (Reichart).

Assignment of glycine modification in derivatives 5 and 6 were made by anaerobic hydrazinolysis of the peptides at $110^{\circ} \mathrm{C}$ for $24 \mathrm{~h}$ (Schroeder, 1972). Separation of the hydrazinolysis products of 1,5 and 6 as well as glycylhydrazide and $\gamma$-glutamylhydrazide standards by cellulose or silica chromatography developed in butanol/acetic acid/water (12:3:5, by vol.) and revealed with ninhydrin, allowed differential comparisons and assignment of 5 and 6 to be made. Separation of the hydrazinolysis products of 1, 5 and 6 were also effected after derivatization with phenyl isothiocyanate/triethylamine reagent before separation on a Waters Pico Tag column with a two-part linear gradient (Tarr, 1986).

$S$-(4-Bromobenzyl)glutathione (1) (Vince et al., 1971) and $N$ benzyloxycarbonyl-S-(4-bromobenzyl)glutathione (4) (D'Silva et al., 1982) were prepared by literature procedures or modifications thereof.

\section{S-(4-Bromobenzyl)glutathione methyl glycinate (5)}

To an ice-cooled suspension of $S$-(4-bromobenzyl)glutathione (1) $(2.0 \mathrm{~g} ; 4.2 \mathrm{mmol})$ in methanol $(40 \mathrm{ml})$ was added dropwise thionyl chloride $(0.4 \mathrm{ml} ; 5.5 \mathrm{mmol})$ and the solution left at room temperature for $4 \mathrm{~h}$ with occasional agitation. The solution was then evaporated to an oil, redissolved in a small amount of methanol and purified by column chromatography on Dowex-1 (1X4-400; formate form; $2.0 \mathrm{~cm} \times 20 \mathrm{~cm}$ column; methanol eluant). Fractions containing the product were pooled, evaporated and recrystallized from methanol/water to give a colourless solid, $0.54 \mathrm{~g}(26.0 \%)$, m.p. $185-187^{\circ} \mathrm{C}$ (negative $\mathrm{AgNO}_{3}$ test). [Found: C, 43.7; $\mathrm{H}, \quad 5.0 ; \mathrm{N}, \quad 7.9$. $\mathrm{C}_{18} \mathrm{H}_{24} \mathrm{~N}_{3} \mathrm{O}_{6} \mathrm{SBr}, \frac{1}{2} \mathrm{H}_{2} \mathrm{O}\left(M_{\mathrm{r}} 498.36\right)$ requires $\mathrm{C}, 43.4 ; \mathrm{H}, 5.0 ; \mathrm{N}$, $8.4 \%$ ]; i.r.: $\nu(\mathrm{NaCl}): \mathrm{CO}_{2} \mathrm{CH}_{3}(1710), \mathrm{NH}(3250) \mathrm{cm}^{-1} ; \delta_{\mathrm{H}}$ (p.p.m.) ([2 $\left.\mathrm{H}_{6}\right]$ dimethyl sulphoxide $\left./{ }^{2} \mathrm{H}_{2} \mathrm{O}\right) \quad 7.4 \quad[4 \mathrm{H}, \mathrm{m}$, Ar(aromatic)-H], $4.5(1 \mathrm{H}, \mathrm{m}, \mathrm{CH}), 3.85\left(2 \mathrm{H}, \mathrm{s}, \mathrm{CH}_{2}-\mathrm{S}\right), 3.7(2 \mathrm{H}$, s, $\left.\mathrm{CH}_{2} \mathrm{~S}\right), 3.6\left(3 \mathrm{H}, \mathrm{s}, \mathrm{O}-\mathrm{CH}_{3}\right), 3.4(1 \mathrm{H}, \mathrm{m}, \mathrm{CH}), 2.6-2.0(6 \mathrm{H}, \mathrm{m}$, Gly- $\mathrm{CH}_{2}$, Glu- $\left.\mathrm{CH}_{2} \mathrm{CH}_{2}\right): \delta_{\mathrm{c}}$ (p.p.m.) $\left(\left[{ }^{2} \mathrm{H}_{6}\right]\right.$ dimethyl sulphoxide) 26.1, 30.7, 33.26, 34.5, 40.38, $\left(5 \times \mathrm{CH}_{2}\right), 51.75\left(\mathrm{C}_{\alpha}, \mathrm{OCH}_{3}\right), 52.8$ $\left(C_{\alpha}\right), 119.9,129.9,131.2,137.95(4 \times \mathrm{Ar}-\mathrm{C}), 169.6,170.0,170.58$, $170.8,171.0(5 \times \mathrm{C}=\mathrm{O})$.

\section{$S$-(4-Bromobenzyl)glutathione glycinamide (6)}

$S$-(4-Bromobenzyl)glutathione (1) $(2.0 \mathrm{~g}: 4.2 \mathrm{mmol})$ was converted into $S$-(4-bromobenzyl)glutathione methyl glycinate (5) as described above and the resultant oil obtained prior to purification by column chromatography treated with $\mathrm{NH}_{3}$ (gas)-saturated methanol $(50 \mathrm{ml})$ with agitation to aid solubilization and the solution left for $60 \mathrm{~h}$ at room temperature. The solution was then evaporated and the residue twice recrystallized from ethanol/ water to give a colourless solid, $0.63 \mathrm{~g}(29.9 \%)$, m.p. 189$190{ }^{\circ} \mathrm{C}$. [Found: $\mathrm{C}, 40.55 ; \mathrm{H}, 5.0 ; \mathrm{N}, 10.8 \mathrm{C}_{17} \mathrm{H}_{23} \mathrm{~N}_{4} \mathrm{O}_{5} \mathrm{SBr}, 1 \frac{1}{2} \mathrm{H}_{2} \mathrm{O}$ $\left(M_{\mathrm{r}} 502.39\right)$ requires $\mathrm{C}, 40.64 ; \mathrm{H}, 5.2 ; \mathrm{N}, 11.15 \%$ ]; i.r.: $v$ $(\mathrm{NaCl}): \mathrm{CONH}_{2}(1650)$, CONH $(1550,1530), \mathrm{NH}(3290) \mathrm{cm}^{-1}$. $\delta_{\mathrm{H}}$ (p.p.m.) $\left(\left[{ }^{2} \mathrm{H}_{6}\right]\right.$ dimethyl sulphoxide) $8.6(2 \mathrm{H}, \mathrm{m}, \mathrm{NH}), 7.4$ (4H, m, Ar-H), $4.0-4.8\left(\mathrm{H}_{2} \mathrm{O}\right), 3.8\left(4 \mathrm{H}, \mathrm{m}, 2 \times \mathrm{CH}_{2}-\mathrm{S}\right), 3.4(1 \mathrm{H}$, $\mathrm{m}, \mathrm{CH})$, 2.7-2.0 (6H, m, Gly- $\mathrm{CH}_{2}$, Glu- $\left.\mathrm{CH}_{2} \mathrm{CH}_{2}\right)$.

\section{$N$-Benzyloxycarbonyl-S-(4-bromobenzyl)glutathione dimethyl ester (9)}

To $N$-benzyloxycarbonyl-S-(4-bromobenzyl)glutathione (4) $(2.8 \mathrm{~g} ; 4.58 \mathrm{mmol})$ dissolved in methanol $(200 \mathrm{ml})$ was added dropwise thionyl chloride $(1 \mathrm{ml} ; 13.78 \mathrm{mmol})$. After $12 \mathrm{~h}$ at room temperature the colourless product was filtered and recrystallized from methanol to give a colourless solid, $2.6 \mathrm{~g}$ $(88.7 \%)$, m.p. $160-163{ }^{\circ} \mathrm{C}$. [Found: C, $50.6 ; \mathrm{H}, 5.0 ; \mathrm{N}, 6.5$. $\mathrm{C}_{27} \mathrm{H}_{32} \mathrm{~N}_{3} \mathrm{O}_{8} \mathrm{SBr}\left(M_{\mathrm{r}} 638.5\right)$ requires C, 50.8; H, 5.05; N, $6.6 \%$ ]; i.r.: $\nu(\mathrm{NaCl}): \mathrm{CO}_{2} \mathrm{CH}_{3}$ (1740), $\mathrm{NH}\left(3340 \mathrm{~cm}^{-1}\right) . \delta_{\mathrm{H}}$ (p.p.m) ( $\left[{ }^{2} \mathrm{H}_{6}\right]$ dimethyl sulphoxide) 8.4-7.6 (3H, m, NH), $7.2(9 \mathrm{H}, \mathrm{s}$, $\mathrm{Ar}-\mathrm{H}), 4.8\left(2 \mathrm{H}, \mathrm{s}, \mathrm{N}-\mathrm{CO}_{2} \mathrm{CH}_{2}-\mathrm{Ph}\right), 4.4(1 \mathrm{H}, \mathrm{m}, \mathrm{CH}), 3.7(1 \mathrm{H}, \mathrm{m}$, $\mathrm{CH}), 3.5\left(4 \mathrm{H}, \mathrm{s}, 2 \times \mathrm{CH}_{2}-\mathrm{S}\right), 3.2\left(6 \mathrm{H}, \mathrm{s}, \mathrm{CO}_{2} \mathrm{CH}_{3}\right), 2.4-2.0$ (6H, m, Gly- $\mathrm{CH}_{2}$, Glu- $\mathrm{CH}_{2} \mathrm{CH}_{2}$ ).

\section{$S$-(4-Bromobenzyl)glutathione dimethyl ester hydrobromide (7)}

To $N$-benzyloxycarbonyl- $S$-(4-bromobenzyl)glutathione dimethyl ester (9) $(0.6 \mathrm{~g} ; 0.94 \mathrm{mmol})$ protected from moisture was added $45 \% \mathrm{HBr} /$ acetic acid $(\mathrm{BDH})(10 \mathrm{ml})$. The solution was gently agitated until all the compound had dissolved (15 min) and then precipitated with dry diethyl ether $(50 \mathrm{ml})$. Successive decantation of the product in diethyl ether freed it of traces of $\mathrm{HBr}$ to recover $0.46 \mathrm{~g} \mathrm{(84.5 \% )}$ of hygroscopic colourless solid, m.p. 45-49 ${ }^{\circ} \mathrm{C}$. [Found: C, 38.45; $\mathrm{H}, 4.8 ; \mathrm{N}, 7.1 . \mathrm{C}_{19} \mathrm{H}_{27} \mathrm{~N}_{3} \mathrm{O}_{6} \mathrm{SBr}_{2}$ $\left(M_{\mathrm{r}} 585.33\right)$ requires $\mathrm{C}, 38.99 ; \mathrm{H} ; 4.65 ; \mathrm{N}, 7.2 \%$ ]; i.r.: $\nu(\mathrm{NaCl})$ : $\mathrm{CO}_{2} \mathrm{CH}_{3}$ (1740), $\mathrm{NH}(3250) \mathrm{cm}^{-1} . \delta_{\mathrm{H}}$ (p.p.m) $\left({ }^{2} \mathrm{H}_{2} \mathrm{O}\right) 7.1(4 \mathrm{H}, \mathrm{m}$, $\mathrm{Ar}-\mathrm{H}), 4.45$ (1H, m, C-H), $3.9\left(2 \mathrm{H}, \mathrm{s}, \mathrm{CH}_{2}-\mathrm{S}\right), 3.75\left(2 \mathrm{H}, \mathrm{s}, \mathrm{CH}_{2}-\right.$ S), $3.55\left(6 \mathrm{H}, \mathrm{s}, \mathrm{CO}_{2} \mathrm{CH}_{3}\right), 2.75-2.2\left(6 \mathrm{H}, \mathrm{m}, \mathrm{Gly}-\mathrm{CH}_{2}, \mathrm{Glu}-\mathrm{CH}_{2}-\right.$ $\mathrm{CH}_{2}$ ). Positive ninhydrin test.

\section{$N$-Benzyloxycarbonyl-S-(4-bromobenzyl)glutathione diamide (10)}

$N$-Benzyloxycarbonyl-S-(4-bromobenzyl)glutathione dimethyl ester (9) (1 g; $1.56 \mathrm{mmol})$ was dissolved in hot methanol $(80 \mathrm{ml})$, cooled, and then the solution saturated with $\mathrm{NH}_{3}$ (gas) and left lightly stoppered at room temperature for $80 \mathrm{~h}$. The solution was then evaporated and the residue recrystallized from methanol/water with hot filtration to give a colourless solid, $0.52 \mathrm{~g}(54.6 \%)$, m.p. $230-232$ (decomp.) ${ }^{\circ} \mathrm{C}$. [Found : C, 49.4; H, 5.2; $\mathrm{N}, 11.6 . \mathrm{C}_{25} \mathrm{H}_{30} \mathrm{~N}_{5} \mathrm{O}_{6} \mathrm{SBr}\left(M_{\mathrm{r}} 608.52\right)$ requires $\mathrm{C}, 49.35 ; \mathrm{H}$, $5.0 ; \mathrm{N}, 11.5 \%] ; \delta_{\mathrm{H}}$ (p.p.m) $\left({ }^{2} \mathrm{H}_{6}\right]$ dimethyl sulphoxide) $8.3^{*}(2 \mathrm{H}$, m, NH), 7.4-7.1 (10H, m, Ar-H), 5.0 (2H, s, N- $\left.\mathrm{CO}_{2} \mathrm{CH}_{2}-\mathrm{Ph}\right), 4.4$ (1H, m, - CH), 3.9 (1H, m, CH), $3.7\left(4 \mathrm{H}, \mathrm{s}, 2 \times \mathrm{CH}_{2}-\mathrm{S}\right), 2.7-2.0$ $\left(6 \mathrm{H}, \mathrm{m}, \mathrm{Gly}-\mathrm{CH}_{2}, \mathrm{Glu}-\mathrm{CH}_{2}-\mathrm{CH}_{2}\right)$.

\section{S-(4-Bromobenzyl)glutathione diamide hydrobromide (8)}

This was prepared from $N$-benzyloxycarbonyl-S-(4bromobenzyl)glutathione diamide (10) $(0.28 \mathrm{~g} ; 0.46 \mathrm{mmol})$ using the same procedure as described for compound (7). The product was obtained as an extremely hygroscopic colourless solid, $0.27 \mathrm{~g} \mathrm{(84.0 \% ).} \mathrm{[Found:} \mathrm{C}, 32.5 ; \mathrm{H}, 4.4 ; \mathrm{N}, 9.6$. $\mathrm{C}_{17} \mathrm{H}_{25} \mathrm{~N}_{5} \mathrm{O}_{4} \mathrm{SBr} \cdot \mathrm{HBr} \cdot \mathrm{C}_{2} \mathrm{H}_{5} \mathrm{OH}\left(M_{\mathrm{r}} 698\right)$ requires $\mathrm{C}, 32.7 ; \mathrm{H}$, 4.6; N, 10.0]; $\delta_{\mathrm{H}}$ (p.p.m) $\left({ }^{2} \mathrm{H}_{2} \mathrm{O}\right) 7.2(4 \mathrm{H}, \mathrm{m}, \mathrm{Ar}-\mathrm{H}), 4.7\left(\mathrm{~s}, \mathrm{H}_{2} \mathrm{O}\right)$, $4.3(1 \mathrm{H}, \mathrm{m}, \mathrm{C}-\mathrm{H}), 4.0(1 \mathrm{H}, \mathrm{m}, \mathrm{C}-\mathrm{H}), 3.8\left(2 \mathrm{H}, \mathrm{s}, \mathrm{CH}_{2}-\mathrm{S}\right), 3.6(2 \mathrm{H}$, s, $\left.\mathrm{CH}_{2}-\mathrm{S}\right), 3.2\left(2 \mathrm{H}, \mathrm{m}, \mathrm{CH}_{3} \mathrm{CH}_{2} \mathrm{OH}\right), 2.8-2.1\left(6 \mathrm{H}, \mathrm{m}, \mathrm{Gly}-\mathrm{CH}_{2}\right.$, Glu- $\left.\mathrm{CH}_{2}-\mathrm{CH}_{2}\right), 1.2\left(3 \mathrm{H}, \mathrm{m}, \mathrm{CH}_{3} \mathrm{CH}_{2} \mathrm{OH}\right)$. Positive ninhydrin test.

\section{RESULTS AND DISCUSSION}

The reaction sequence employed for the synthesis of compounds 4-10 is shown in Scheme 1. The thionyl chloride/methanol procedure was used for the selective formation of the glycyl monomethyl ester derivative (5) from 1. This procedure is sufficiently specific that greater than 1 equiv. of reagent can be added with no significant difficulty associated in purification of the ester derivative. Purification of the ester to remove trace amounts of dimethyl ester which may have formed was achieved by Dowex (1X4-400) column chromatography.

The selectivity of the reaction when undertaken at room temperature or ice-cold conditions is associated both with the $\mathrm{p} K_{\mathrm{a}}$ values of the carboxy groups $(\gamma-3.73 ; \alpha-2.12)$ (Vander Jagt $\&$ Han, 1973) and the presence of the free $\alpha$-amino group. Since the $\alpha$-amino group is acid-strengthening with respect to the $\alpha$ $\mathrm{CO}_{2} \mathrm{H}$ group, hence the lower $\mathrm{p} K_{\mathrm{a}}(\alpha 2.12)$, its protection would 


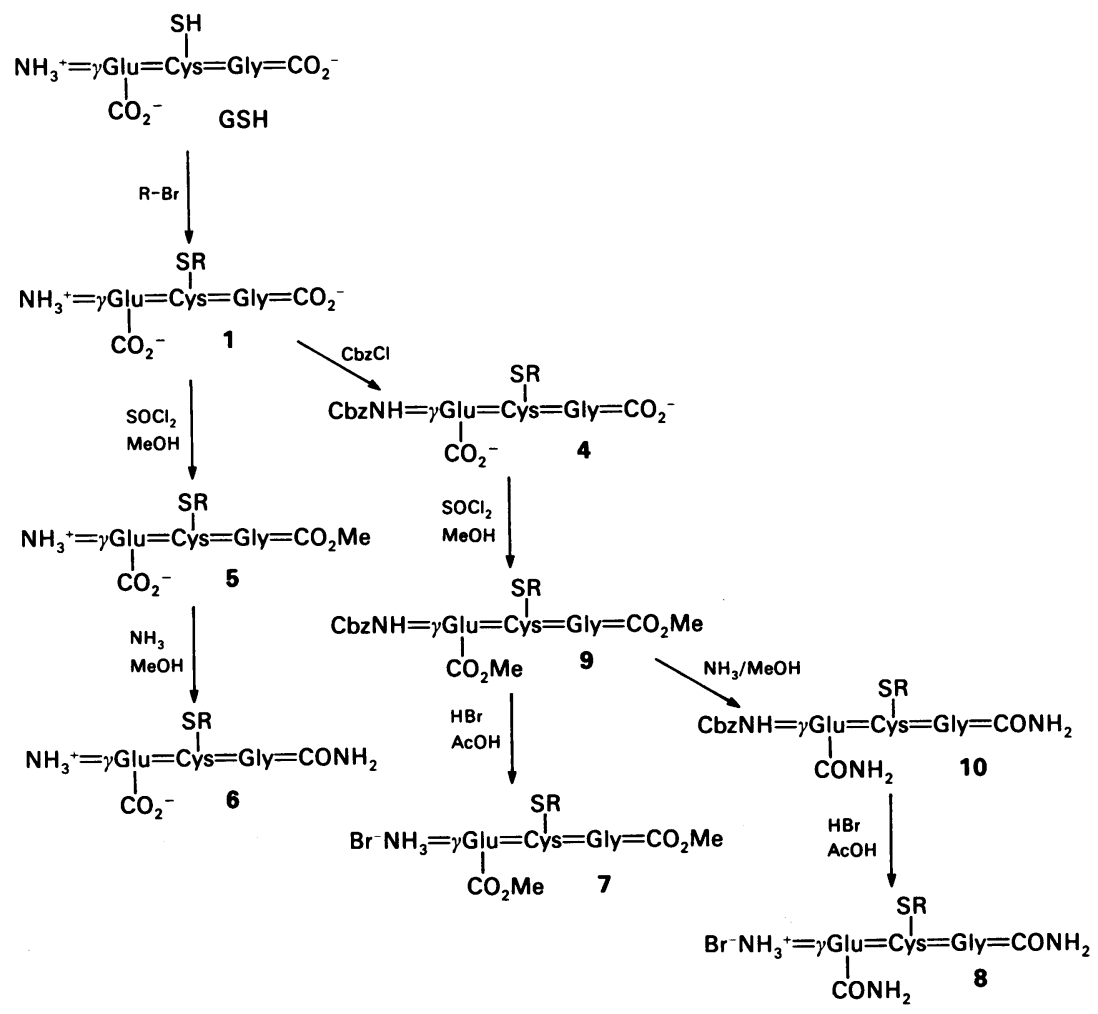

Scheme 1. Reaction sequence employed for the synthesis of compounds 4-10

Abbreviations used: $\mathrm{Cbz}$, benzyloxycarbonyl; $\mathrm{MeOH}$, methanol; $\mathrm{AcOH}$, acetic acid; $\mathrm{R}, \mathrm{p}-\mathrm{Br}-\mathrm{C}_{6} \mathrm{H}_{4} \mathrm{CH}_{2}-$.

therefore be expected to reduce the acidity of the $\alpha-\mathrm{CO}_{2} \mathrm{H}$ group $\left(\mathrm{p} K_{\mathrm{a}}>2.12\right)$ and result in loss of selectivity of methylation. As expected protection of the $\alpha$-amino group with the benzyloxycarbonyl group resulted in complete loss of selectivity and a high yield $(88.7 \%$ ) of the dimethyl ester (9). Both for the monomethyl and dimethyl esters conversion into the corresponding amide derivative 6 and 10 respectively was achieved through incubation with $\mathrm{NH}_{3}$ /methanol. The free amino forms of derivatives $\mathbf{7}$ and $\mathbf{8}$ were obtained as their hydrobromide salts by treatment of 9 and 10 respectively with $\mathrm{HBr} /$ acetic acid.

Compounds 5 and 6 were isolated from aqueous solutions with various amounts of water of hydration; however, both compounds were not perceptibly hygroscopic. Compounds 7 and 8 were hygroscopic and the latter was isolated and found to contain ethanol, a product of $\mathrm{HBr}$-catalysed hydrolysis of diethyl ether.

The availability of amino- and carboxy-modified glutathione analogues has allowed us to map systematically the GSH-binding site of enzymes such as yeast glyoxalase I (Douglas et al., 1982b; D'Silva, 1986) and equine liver glutathione transferase [the preceding paper (D'Silva, 1990)]. On the basis of these studies we have implicated the glycine carboxy group of yeast glyoxalase I in intramolecular participation via a histidine residue in the catalytic mechanism of the enzyme (D'Silva, 1986). In the case of glutathione transferase we propose involvement of the $\mathrm{N}$-amino and glutamic acid and glycine carboxy groups of GSH with electrostatic interaction with the corresponding sites located on the enzyme.
The generality of the procedure described here to the synthesis of carboxy-group-modified glutathiones has been demonstrated by the successful applicaiion of the technique to the preparation of derivatives of the hexapeptide, oxidized glutathione.

I am grateful to Mr. A. R. Griffiths for drawing the Figures, the GEC/Fellowship of Engineering for the award of a Senior Fellowship and the Science and Engineering Research Council for their support.

\section{REFERENCES}

Adang, A. E., Duindam, A. J. G., Brussee, J., Mulder, G. J. \& van der Gen, A. (1988) Biochem. J. 255, 715-720

Askelof, P., Guthenberg, C., Jakobson, I. \& Mannervik, B. (1975) Biochem. J. 147, 513-522

Boisonnas, R. A., Guttman, S., Jaguenoud, P. A. \& Waller, J. P. (1955) Helv. Chim. Acta 38, 1491-1501

Chen, W.-J., Boehlert, C. C., Rider, K. \& Armstrong, R. N. (1985) Biochem. Biophys، Res. Commun. 142, 441-447

Douglas, K. T., Seddon, A. P., D'Silva, C. \& Bunni, M. (1982a) Biochem. Soc. Trans. 10, 124-125

Douglas, K. T., Al-Timari, A., D'Silva, C. \& Gobel, D. I. (1982b) Biochem. J. 207, 323-329

D'Silva, C. (1986) FEBS Lett. 202, 240-244

D'Silva, C. (1990) Biochem. J. 271, 161-165

Schroeder, W. A. (1972) Methods Enzymol. 25B, 138

Tarr, G. E. (1986) in Microcharacterization of Polypeptides: A Practical Manual (Shively, J. E., ed.), pp. 155-194, Humana Press, Clifton, NJ

Vander Jagt, D. L. \& Han, L.-P. B. (1973) Biochemistry 12, 5161-5167

Vince, R., Daluge, S. \& Wadd, W. B. (1971) J. Med. Chem. 14, 402-404 